\title{
Papers
}

\section{Multiplex polymerase chain reaction for the simultaneous detection of Mycoplasma pneumoniae, Chlamydia pneumoniae, and Chlamydia psittaci in respiratory samples}

\author{
C Y W Tong, C Donnelly, G Harvey, M Sillis
}

\begin{abstract}
Aims-To develop a multiplex polymerase chain reaction (PCR) for the simultaneous detection of Mycoplasma pneumoniae, Chlamydia pneumoniae, and Chlamydia psittaci in respiratory samples.

Methods-Oligonucleotide primers for the amplification of the DNA of these three organisms were optimised for use in combination in the same reaction. PCR products were detected by hybridisation with pooled internal probes using an enzyme linked immunosorbent assay. Those with positive signals were further differentiated using species specific probes. Quality of DNA extraction and PCR inhibition were controlled by amplification of a human mitochondrial gene. A panel of 53 respiratory samples with known results was evaluated blindly. This was followed by a retrospective study on sputa collected from 244 patients with suspected community acquired pneumonia.

Results-The multiplex assay had a lower sensitivity than PCR with individual primers by about one log. The resultant sensitivity was considered acceptable for diagnostic use. Of the panel of 53 samples, nine of $11 \mathrm{M}$ pneumoniae, 11 of $11 \mathrm{C}$ pneumoniae, six of seven $C$ psittaci, and 24 of 24 negative samples were correctly identified. Of the 244 patients with pneumonia, seven (2.9\%) had detectable $M$ pneumoniae, six $(2.5 \%)$ had $C$ pneumoniae, and one $(0.4 \%)$ had $C$ psittaci. The case notes from 11 patients were studied. The PCR finding was of possible significance in at least eight of these patients.
\end{abstract}

Conclusions-This multiplex PCR assay has the potential to be used as a diagnostic and epidemiological tool. Further prospective studies are needed to establish its clinical value.

(f Clin Pathol 1999;52:257-263)

Keywords: atypical pneumonia; polymerase chain reaction; Mycoplasma pneumoniae; Chlamydia pneumoniae; Chlamydia psittaci
Mycoplasma and chlamydia are major causes of community acquired atypical pneumonia. ${ }^{1-3}$ Mycoplasma pneumoniae activity occurs in the United Kingdom in predictable four yearly cycle. So far, outbreaks have been documented during 1983, 1987, 1991, and 1995.. Chlamydia pneumoniae is rare in children under five but becomes more common with increasing age, ${ }^{6}$ with an adult seroprevalence of up to $40-70 \% .^{7}$ Chlamydia psittaci, a zoonosis acquired from avian exposure, is less common than Mycoplasma pneumoniae and Chlamydia pneumoniae, but is still an important pathogen in the United Kingdom, with reported outbreaks involving contact with psittacine birds ${ }^{8}$ and poultry, ${ }^{9}$ causing severe systemic illness in addition to pneumonia. Culture of these organisms is difficult and time consuming. ${ }^{11}{ }^{11}$ Differentiation between $M p$ neumoniae and $M$ genitalium, both of which can be isolated from respiratory samples, is not easy, ${ }^{12}{ }^{13}$ and the culture of $C$ psittaci could be hazardous. ${ }^{14}$ Frequently, insensitive and cross reacting serological techniques, ${ }^{15-17}$ such as the complement fixation test, are being used as the main diagnostic test. As a result of these factors, and also of the timing of the research, conflicting prevalences of these atypical infections have been reported, ranging from $1 \%$ to $40 \% .{ }^{1-3} 18{ }^{19}$ Many recent studies have explored the use of the polymerase chain reaction (PCR) to detect either mycoplasma or chlamydia in atypical pneumonia. ${ }^{20-26}$ Here, we report on the development and evaluation of a multiplex PCR that could simultaneously detect and differentiate these three organisms in respiratory samples.

\section{Methods}

PANEL OF KNOWN POSITIVE AND NEGATIVE SAMPLES

A panel of 53 respiratory samples, thoroughly investigated previously using direct antigen detection, culture, serology, and $\mathrm{PCR}^{25}{ }^{27}$ for mycoplasma and chlamydia, was used for the initial evaluation of the multiplex PCR assay. The samples were collected over many years by the Norwich Public Health Laboratory and the University of Liverpool and were stored at 
Table 1 Test results of the positive members of the evaluation panel

\begin{tabular}{|c|c|c|c|c|c|}
\hline Samples & $\begin{array}{l}\text { Direct } \\
\text { antigen } \\
\text { detection }^{a}\end{array}$ & Culture & Serology & $\begin{array}{l}\text { Previous } \\
\text { PCR }^{b}\end{array}$ & $\begin{array}{l}\text { Multiplex } \\
\text { PCR }\end{array}$ \\
\hline \multicolumn{6}{|c|}{ M pneumoniae } \\
\hline 1 & NA & Neg & Pos & Pos & Neg \\
\hline 2 & NA & Pos & Pos & Pos & Pos \\
\hline 3 & NA & Neg & Pos & NT & Pos \\
\hline 4 & NA & Pos & Pos & Pos & Pos \\
\hline 5 & NA & Pos & Pos & Pos & Pos \\
\hline 6 & NA & Pos & Pos & Pos & Neg \\
\hline 7 & NA & Pos & Pos & Pos & $\operatorname{Pos}^{c}$ \\
\hline 8 & NA & Neg & Pos & Neg & Pos \\
\hline 9 & NA & Pos & Pos & Pos & Pos \\
\hline 10 & NA & Neg & Pos & Pos & Pos \\
\hline 11 & NA & $\mathrm{Neg}$ & Pos & $\mathrm{Neg}$ & Pos \\
\hline \multicolumn{6}{|c|}{ C pneumoniae } \\
\hline 1 & Pos & Neg & Pos & Pos & Pos \\
\hline 2 & Pos & Neg & Pos & Pos & Pos \\
\hline 3 & Pos & $\mathrm{Neg}$ & Pos & Pos & Pos \\
\hline 4 & Pos & Neg & Pos & Pos & Pos \\
\hline 5 & Pos & $\mathrm{Neg}$ & Pos & Pos & Pos \\
\hline 6 & Pos & Neg & Pos & Pos & Pos \\
\hline 7 & Pos & Neg & Pos & Pos & Pos \\
\hline 8 & Pos & Neg & NA & Pos & Pos \\
\hline 9 & Pos & Neg & Pos & Pos & $\operatorname{Pos}^{\mathrm{c}}$ \\
\hline 10 & NT & NT & NA & Pos & Pos \\
\hline 11 & NT & NT & NA & Pos & Pos \\
\hline \multicolumn{6}{|c|}{$C$ psittaci } \\
\hline 1 & Pos & Neg & Neg & Pos & Pos \\
\hline 2 & Pos & $\mathrm{Neg}$ & $\mathrm{Neg}$ & Pos & Pos \\
\hline 3 & Pos & NT & Pos & Pos & Pos \\
\hline 4 & Pos & NT & Pos & $\mathrm{Neg}$ & $\mathrm{Neg}^{\mathrm{d}}$ \\
\hline 5 & Pos & NT & Pos & Pos & $\operatorname{Pos}^{\mathrm{c}}$ \\
\hline 6 & Pos & Neg & Pos & Pos & Pos \\
\hline 7 & Pos & NT & Pos & NT & Pos \\
\hline
\end{tabular}

NA, test or sample not available; NT, not tested.

${ }^{a}$ Direct antigen detection for chlamydia included ELISA and direct immunofluorescence, not applicable fpr mycoplasma. brevious PCR performed according to refs 25 and 28 .

Positive after dilution.

${ }^{\mathrm{d}}$ Both multiplex PCR and human DNA PCR remained negative after dilution.

$-20^{\circ} \mathrm{C}$. The expected results included: $M$ pneumoniae ( $\mathrm{n}=11), C$ pneumoniae $(\mathrm{n}=11)$, $C$ psittaci $(\mathrm{n}=7)$, and negative $(\mathrm{n}=24)$. All the positive samples of the panel contained a single organism with no double infection. The details of these positive samples, some of which had previously been reported, ${ }^{25}$ are listed in table 1 . The negative samples were random specimens with little known clinical information but were tested negative for mycoplasma and chlamydia previously. To test the specificity of the assay, three of the known negative samples were also spiked with $M$ salivarium, $M$ genitalium, and $M$ orale.

HOSPITAL BASED STUDY

Sputum samples $(n=279)$ from 244 patients (mean age 60 years, range 5 to $95 ; 122$ females and 122 males) with suspected community acquired pneumonia, received and stored by the department of medical microbiology of the Royal Liverpool University Hospital during the winter of 1996-1997, were studied retrospectively using the multiplex assay.

SPECIMEN PREPARATION AND DNA EXTRACTION An aliquot of each sputum sample was diluted 1 in 5 with phosphate buffered saline (PBS) and centrifuged for 10 minutes in a microfuge at $12000 \mathrm{~g}$. Supernatant was discarded and the pellet was resuspended in $200 \mu 1$ of PBS. DNA extraction was performed using the QIAamp blood kit (Qiagen) according to the blood and body fluid protocol recommended by the manufacturer. Briefly, the sample was digested with the supplied protease at $70^{\circ} \mathrm{C}$ for $10 \mathrm{~min}$ utes, precipitated in ethanol, and centrifuged through a spin column. The spin column with the bound DNA was washed and eluted in 200 $\mu 1$ of the supplied AE buffer. These were tested either immediately or stored at $-20^{\circ} \mathrm{C}$.

\section{POLYMERASE CHAIN REACTION AND PRODUCT} DETECTION

The PCR primers for mycoplasma (P4A, P4B) and chlamydia (CP1, CP2) were described previously; they respectively amplify a $345 \mathrm{bp}$ region of the P1 adhesin gene of $M$ pneumoniae ${ }^{22}$ and a $333 \mathrm{bp}$ region of the major outer membrane protein gene of both $C$ pneumoniae and $C$ psittaci. ${ }^{25}$ The reverse primers $\mathrm{P} 4 \mathrm{~B}$ and $\mathrm{CP} 2$ were both biotinylated at the $5^{\prime}$ end to facilitate PCR product detection (Life Technologies). PCR reactions for mycoplasma and chlamydia were initially evaluated separately using serial dilutions of culture materials. The reactions were subsequently combined. Optimisation of the multiplex assay was performed by testing different combinations of primer concentration and magnesium concentration, using a fixed dilution of the culture materials at about $2 \log$ above the detection threshold of the individual assays, to establish a combination with the most comparable result. The annealing temperature was set at $60^{\circ} \mathrm{C}$ as a compromise between the original individual PCRs (Touchdown PCR from $65^{\circ} \mathrm{C}$ to $55^{\circ} \mathrm{C}$ for chlamydia and $65^{\circ} \mathrm{C}$ for mycoplasma).

Apart from the annealing temperature, the condition of the optimised multiplex PCR assay was not significantly different from the individual assays and consisted of $10 \mu \mathrm{l}$ of extracted DNA per reaction with $20 \mathrm{mM}$ Tris $\mathrm{HCl}, \mathrm{pH} 8.4,50 \mathrm{mM} \mathrm{KCl}, 1.5 \mathrm{mM} \mathrm{MgCl} 2,200$ $\mu \mathrm{M}$ of dNTP, $0.5 \mu \mathrm{M}$ of each primer, and 0.6 units of Taq polymerase (Life Technologies) in a final volume of $50 \mu$ l.

Thermocyclers with heated lids (Perkin Elmer 2400 or 9600) were used and the programme consisted of an initial denaturation at $94^{\circ} \mathrm{C}$ for five minutes, followed by 40 cycles of $94^{\circ} \mathrm{C}$ for 30 seconds, $60^{\circ} \mathrm{C}$ for 30 seconds, and $72^{\circ} \mathrm{C}$ for 30 seconds, with a final extension at $72^{\circ} \mathrm{C}$ for 10 minutes. Internal probes were designed for PCR product detection as follows: (1) an $M$ pneumoniae specific probe (P4P: 5' GACTTTCTGAAAGCAACGCCGCAAAGATGA); (2) a $C$ pneumoniae specific probe (CPDP: 5' AAACTATACTACTGCCGTA GAT), and (3) a common probe for both $C$ pneumoniae and $C$ psittaci (CPCP: 5' TTATTAATTGATGGYACWATRTGGGARGG).

Each probe was labelled at the 3' end with digoxigenin using a commercial oligonucleotide 3' end labelling kit (Boehringer Mannheim).

The PCR products were denatured with an equal volume of $1.6 \% \mathrm{NaOH}$ and $1 \mathrm{mM}$ EDTA at room temperature for 20 minutes. Then $10 \mu \mathrm{l}$ of the denatured PCR product was mixed with $100 \mu$ l of hybridisation buffer (Boehringer Mannheim) and $1 \mathrm{pmol}$ of each probe 

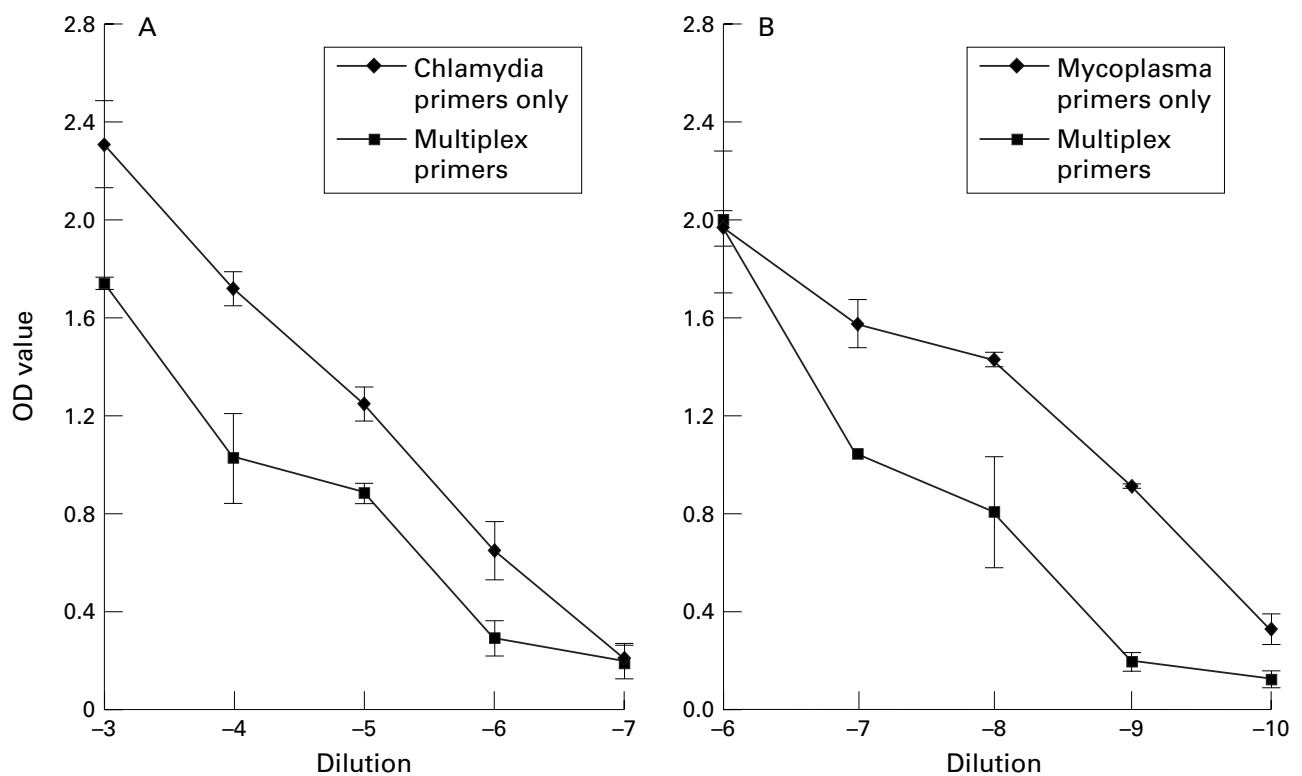

Figure 1 Comparison of multiplex primers with individual primers using a 10-fold dilution series of culture materials. (A) $C$ pneumoniae; (B) $M$ pneumoniae. Cutoff set at $O D=0.4$. Error bar indicates standard error of the mean.

in a streptavidin coated microtitre plate (Labsystems), and hybridised at $40^{\circ} \mathrm{C}$ for one hour. The plate was washed five times with $25 \mathrm{mM}$ Tris $\mathrm{HCl} \mathrm{pH} 7.5,0.15 \mathrm{M} \mathrm{NaCl}, 2 \mathrm{mM} \mathrm{MgCl}$, and $0.1 \%$ Tween 20 . Antidigoxigenin peroxidase conjugate (Boehringer Mannheim) was added to each well (75 $\mathrm{mU}$ in PBS $1 \%$ skimmed milk) and the plate was incubated at $37^{\circ} \mathrm{C}$ for 30 minutes, followed by a $\times 5$ wash with PBS $0.1 \%$ Tween $20 ; 100 \mu$ of 3,3',5,5' tetramethylbenzidine (Sigma) was used as the substrate. This reaction was stopped with 0.5 $M$ sulphuric acid after 10 minutes. The optical density (OD) was read at $450 \mathrm{~nm}$. A pool of the three probes was used in the initial screening, and any positive signal was confirmed and differentiated using the individual probe: a positive signal with $\mathrm{P} 4 \mathrm{P}$ indicates the presence of $M$ pneumoniae, a positive signal with both CPCP and CPDP indicates the presence of $C$ pneumoniae, whereas a positive signal with CPCP only indicates the presence of $C$ psittaci.

Quality of the samples and amplification inhibitors was controlled with a human mitochondrial DNA PCR, using previously described primers (H6A, H6B), ${ }^{22}$ in a separate reaction but using the same format as the multiplex assay. PCR product from the human DNA amplification was similarly detected using the human probe H6P (5' CATCCGTATTACTCGCATCAGGAGTATCAA) in a separate reaction. Samples that showed negative results in both the multiplex assay and the human DNA assay were repeated at 1 in 20 dilution to overcome possible PCR inhibition.

DETERMINATION OF CUTOFF, SENSITIVITY, AND SPECIFICITY

Using the results of serial dilutions of a strain of $C$ pneumoniae (IOL 207) and $M$ pneumoniae (NCTC 10119) and a panel of known positive and negative materials, it was decided to set a provisional cutoff at the OD reading of 0.4 with a "grey zone" of 0.1 on either side. The validity of this cutoff was further determined in a subsequent survey of hospital samples. Sensitivity was correlated by comparing $C$ pneumoniae elementary body count using direct immunofluorescence (DIF) and colony forming unit (CFU) count of $M$ pneumoniae. Sensitivity and specificity were further evaluated by blindly testing the panel of 53 samples with known positive and negative results.

\section{Results}

SERIAL DILUTIONS OF CULTURE

Using the arbitrary cutoff of 0.4 , the chlamydia PCR was positive with individual primers up to a dilution of $10^{-6}$ and the multiplex assay, $10^{-5}$. By comparing with elementary body count by DIF, the multiplex PCR had a detection limit of within 10 elementary bodies per reaction. The mycoplasma PCR was positive with individual primers up to the dilution of $10^{-10}$ and the multiplex assay, $10^{-9}$. By comparing with CFU count, the multiplex PCR had a detection limit of between 10 and 20 CFU per reaction. Overall, the sensitivity of each PCR dropped by 1 log when the assays were combined (fig 1). However, the resultant reaction still had a detection limit of within 10-20 organisms and is therefore considered acceptable as a diagnostic test, but this has still to be clinically evaluated.

\section{PANEL OF KNOWN POSITIVE AND NEGATIVE} SAMPLES

Of the 11 expected $M$ pneumoniae samples, eight were correctly identified by the initial multiplex assay. One sample had no detectable human DNA and was retested after 1:20 dilution; both $M$ pneumoniae and human DNA became detectable after dilution. The two samples missed by the multiplex assay when retested using individual primers also gave negative results, suggesting that the amount of DNA in the sample was below detection limit. 


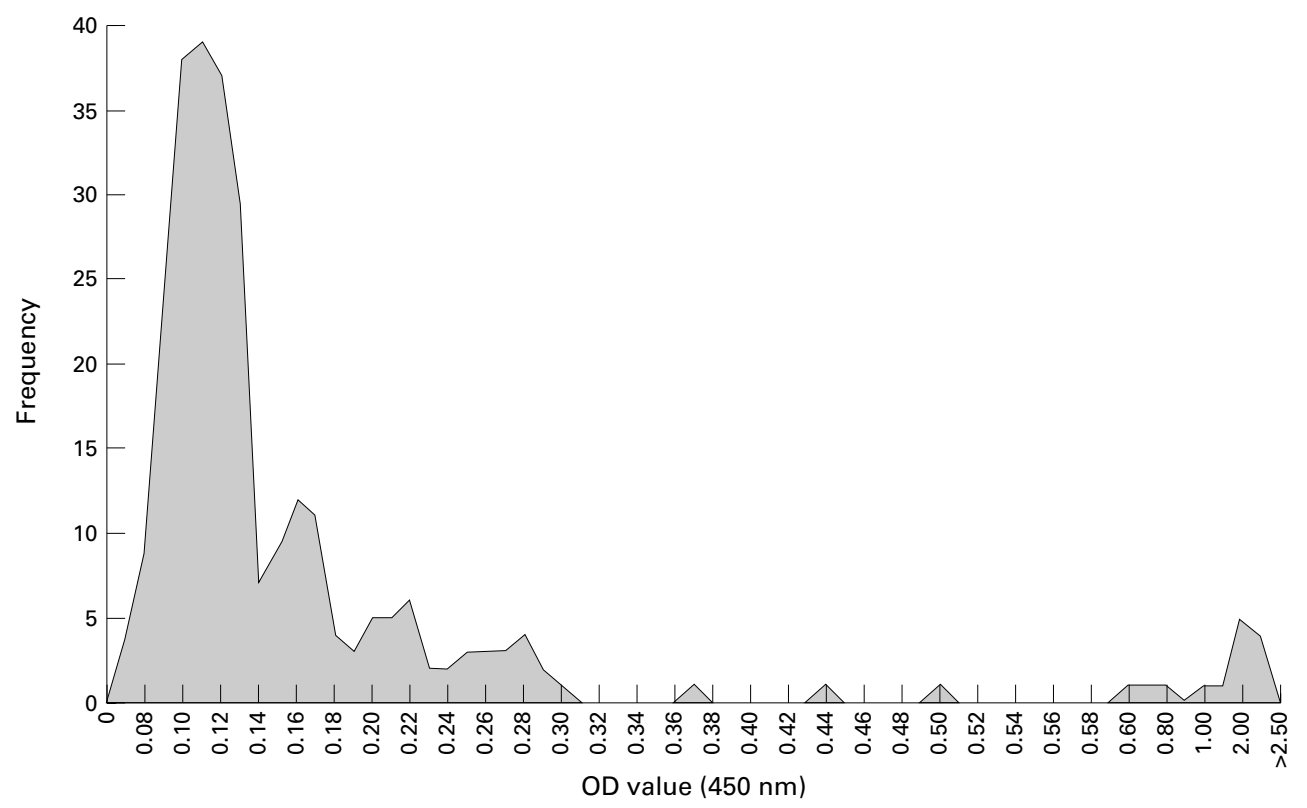

Figure 2 Frequency distribution of $O D$ value of the 279 samples from the hospital series.

Of the 11 expected $C$ pneumoniae samples, 10 were correctly identified by the initial multiplex assay. The remaining sample had no detectable human DNA. Both $C$ pneumoniae and human DNA became detectable after dilution.

Of the seven expected $C$ psittaci samples, five were correctly identified by the initial multiplex assay; the two remaining samples both had undetectable human DNA and were retested after dilution: one had detectable $C$ psittaci DNA after dilution but the other sample remained negative for both $C$ psittaci and human DNA, suggesting either a failure of DNA extraction or a high level of PCR inhibition.

All 24 negative samples were correctly identified as negative by the multiplex assay, with no inhibition and no cross reaction with other mycoplasma species observed. On the basis of the results of this panel of samples and with adjustment for inhibition control by dilution, the sensitivity of the multiplex assay for $M$ pneumoniae, $C$ pneumoniae, and $C$ psittaci were $82 \%(9 / 11), 100 \%(11 / 11)$, and $86 \%$ (6/7) respectively, and the specificity was $100 \%$ $(24 / 24)$. Overall, four of 53 samples $(7.5 \%)$ had negative human DNA PCR and required retesting by dilution.

\section{HOSPITAL BASED STUDY}

The OD readings of the 279 samples (from 244 patients) from the retrospective hospital based study were plotted for distribution analysis and to determine the suitability of the chosen cutoff. The provisional cutoff value of 0.4 clearly distinguished between two groups of samples (fig 2) and therefore was formally adopted as the cutoff for the multiplex assay.

Three samples that had the original OD within the grey zone were repeated: two were negative and one was clearly positive on repeat, suggesting that the initial results could have been caused by a technical error. Of the 279 samples, nine $(3.2 \%)$ had negative human DNA PCR and were therefore retested after dilution. All had detectable human DNA after dilution but remained negative by the multiplex assay and were considered negative. In all, eight sputa from seven patients were positive for $M$ pneumoniae $(7 / 244=2.9 \%)$; six sputa from six patients were positive for $C$ pneumoniae $(6 / 244=2.5 \%)$, and one patient was positive for $C$ psittaci $(1 / 244=0.4 \%)$.

Only 36 of 244 patients had an acute blood sample sent for investigation and none had a convalescent sample. Of the 14 positive patients, only two had an acute blood sample sent for investigation. All of the acute blood samples had negative serological results for $M$ pneumoniae (Serodia-mycoII, Fujirebio) and chlamydia (microimmunofluorescence, IO International).

To study the likelihood of atypical infection, the case notes of 11 patients were retrieved and studied (table 2). Three sets of case notes could not be retrieved. Most of these 11 patients were elderly (seven were over 60 years old) and had predisposing conditions such as chronic obstructive pulmonary disease or steroid treatment (nine patients). Chest radiography was done in seven and radiological evidence of pneumonia was identified in six. On the basis of bacterial culture and response to antibiotics, the multiplex PCR result was considered significant in four of these 11 patients (three $M$ pneumoniae and one $C$ pneumoniae). In a further four patients, other significant bacterial pathogens were isolated, but on the basis of the response to the prescribed antibiotics, the role of either M pneumoniae $(\mathrm{n}=2)$ or $C$ pneumoniae $(\mathrm{n}=2)$ could not be excluded. Two young patients (Nos 9 and 10) with no underlying illness had $C$ pneumoniae DNA detected in sputum, but both responded to antibiotics not suitable for treatment of chlamydia. Though the PCR results in these two cases may seem irrelevant, they may simply indicate that in the 
Table 2 Clinical and radiological features, bacterial culture results, and treatment responses of the 11 patients who had a positive multiplex PCR result

\begin{tabular}{|c|c|c|c|c|c|c|c|c|c|c|}
\hline Patient & $\begin{array}{l}\text { Age } \\
\text { (years) }\end{array}$ & $\begin{array}{l}\text { Predisposing } \\
\text { conditions }\end{array}$ & $\begin{array}{l}\text { Presenting } \\
\text { symptoms }\end{array}$ & $\begin{array}{l}\text { Radiological } \\
\text { evidence of } \\
\text { pneumonia }\end{array}$ & $\begin{array}{l}\text { Bacterial culture } \\
\text { results }\end{array}$ & $\begin{array}{l}\text { Initial } \\
\text { antibiotic } \\
\text { treatment }\end{array}$ & $\begin{array}{l}\text { Response to } \\
\text { initial } \\
\text { treatment }\end{array}$ & $\begin{array}{l}\text { Further } \\
\text { treatment } \\
\text { (with clinical } \\
\text { success) }\end{array}$ & $\begin{array}{l}\text { Multiplex } \\
\text { PCR results }\end{array}$ & $\begin{array}{l}\text { Relevance } \\
\text { and } \\
\text { significance of } \\
\text { PCR result }\end{array}$ \\
\hline 1 & 65 & $\begin{array}{l}\text { Metastatic } \\
\text { carcinoma, COPD }\end{array}$ & $\begin{array}{l}\text { Cough, green } \\
\text { sputum }\end{array}$ & $\mathrm{No}^{\star}$ & Normal flora & Co-amoxiclav & No & Erythromycin & M pneumoniae & Yes \\
\hline 2 & 66 & COPD & Cough, SOB & NA & $\begin{array}{l}\text { B catarrhalis, } S \\
\text { pneumoniae, } H \\
\text { influenzae }\end{array}$ & $\begin{array}{l}\text { Amoxycillin, } \\
\text { erythromycin }\end{array}$ & Yes & None & $M$ pneumoniae & Possible \\
\hline 3 & 58 & $\begin{array}{l}\text { Renal failure, } \\
\text { steroids }\end{array}$ & $\begin{array}{l}\text { Cough, chest } \\
\text { pain }\end{array}$ & Yes & H influenzae & Ciprofloxacin & Slow & None & M pneumoniae & Possible \\
\hline 4 & 77 & COPD & $\begin{array}{l}\text { Cough, } \\
\text { pyrexia }\end{array}$ & Yes & Normal flora & Trimethroprim & No & $\begin{array}{l}\text { Erythromycin, } \\
\text { ciprofloxacin, } \\
\text { amoxycillin }\end{array}$ & M pneumoniae & Yes \\
\hline 5 & 61 & $\begin{array}{l}\text { Mitral valve } \\
\text { replacement, } \\
\text { COPD }\end{array}$ & $\begin{array}{l}\text { Cough, } \\
\text { purulent } \\
\text { sputum }\end{array}$ & Yes & Normal flora & Co-amoxiclav & No & Erythromycin & M pneumoniae & Yes \\
\hline 6 & 74 & COPD & SOB, pyrexia & Yes & $\begin{array}{l}S \text { pneumoniae, } \\
\text { B catarrhalis }\end{array}$ & $\begin{array}{l}\text { Amoxycillin, } \\
\text { erythromycin }\end{array}$ & Yes & None & $C$ pneumoniae & Possible \\
\hline 7 & 49 & $\begin{array}{l}\text { Sarcoidosis, } \\
\text { steroids }\end{array}$ & $\begin{array}{l}\text { Chest pain, } \\
\text { pyrexia }\end{array}$ & Yes & Normal flora & $\begin{array}{l}\text { Ceftriaxone, } \\
\text { erythromycin }\end{array}$ & Yes & None & $C$ pneumoniae & Yes \\
\hline 8 & 60 & COPD & SOB, pyrexia & Yes & $\begin{array}{l}\text { Pseudomonas } \\
\text { sp. }\end{array}$ & Co-amoxiclav & No & $\begin{array}{l}\text { Erythromycin, } \\
\text { ceftriaxone }\end{array}$ & $C$ pneumoniae & Possible \\
\hline 9 & 51 & None & $\begin{array}{l}\text { Pyrexia, } \\
\text { cough }\end{array}$ & NA & Normal flora & Penicillin & Yes & None & $C$ pneumoniae & No \\
\hline 10 & 9 & None & Catarrh & NA & Normal flora & Cefaclor & Yes & None & C pneumoniae & No \\
\hline 11 & 94 & Heart failure & $\begin{array}{l}\text { SOB, } \\
\text { jaundice }\end{array}$ & NA & $\begin{array}{l}\text { B catarrhalis, } \\
\text { MRSA }\end{array}$ & Amoxycillin & No & $\begin{array}{l}\text { Steroid, } \\
\text { frusemide }\end{array}$ & $C$ psittaci & No \\
\hline
\end{tabular}

COPD, chronic obstructive airways disease; NA, chest $x$ ray not taken; MRSA, methicillin resistant Staphylococcus aureus; SOB, shortness of breath. ${ }^{\star}$ The chest $x$ ray of patient 1 showed pulmonary metastases. $B$ catarrhalis $=$ Branhamella catarrhalis.

normal host these infections are self limiting. The significance of the detection of $C$ psittaci DNA in an elderly patient (No 11) with heart failure is not clear. The presence of heart failure in this case and the lack of other investigations make the assessment of response difficult.

\section{Discussion}

Previous workers have reported on the use of PCR to detect mycoplasma and chlamydia in respiratory samples. ${ }^{20-26}$ Since the clinical features of atypical pneumonia caused by mycoplasma and chlamydia are very similar, ${ }^{1}$ it is necessary to have an approach that can detect and differentiate all relevant organisms using the same sample and the same assay. Here we reported the successful development of a multiplex PCR for the simultaneous detection and differentiation of $M$ pneumoniae, $C$ pneumoniae, and $C$ psittaci.

One of the problems we encountered was the fall in sensitivity when assays were combined. Although other successful multiplex assays have previously been reported, ${ }^{22}{ }^{29}{ }^{30}$ multiplex mycoplasma and chlamydia PCR appears to have more sensitivity problem. ${ }^{31}$ In our system, the multiplex assay had a lower sensitivity of about $1 \log$ for both $M$ pneumoniae and $C$ pneumoniae compared with their individual PCRs. We have not determined the sensitivity change for $C$ psittaci. However, since the primer binding site is identical to that of $C$ pneumoniae, we would expect its sensitivity to be similar. The detection limit of the multiplex PCR of within 10-20 organisms should be acceptable for diagnostic use. Also, the performance of the multiplex PCR with the panel suggested a sensitivity of more than $82 \%$ and a specificity of $100 \%$. However, owing to the complexity of the variables in a multiplex PCR which includes different combinations of primer concentrations, magnesium concentrations, and annealing temperatures, the sensitiv- ity could have been further improved by more careful optimisation. In our development, we have performed a limited optimisation using a fixed dilution of cultured materials. Ideally, a clinical sample should have been used as a standard, and a more elaborate optimisation should be performed using the format of multiple chessboard titrations, testing different combinations of the variables. Further optimisation of the annealing temperature is also desirable. It is possible that the "hot start" approach or the use of the new "temperature activated" DNA polymerases could help to improve the sensitivity. Also, the evaluation panel and the clinical samples in this study did not contain double infections. The ability of the multiplex assay to detect dual infections is therefore not known. It is important that this aspect should be addressed in future optimisation and evaluation.

The other problem encountered during the study was PCR inhibition. This was noted more often in the evaluation panel (4/ $53=7.5 \%$ ) than the subsequent clinical series $(9 / 279=3.2 \%)$. The evaluation panel contained much older samples that had been in storage for many years. This may have contributed to the increase in PCR inhibition. All of the samples in the clinical series with negative human DNA had detectable human DNA after dilution, suggesting that PCR inhibition rather than DNA extraction was the problem. The routine inclusion of a human DNA amplification control will help to identify both the problem of DNA extraction failure and PCR inhibition. The failure of the multiplex assay to identify two expected mycoplasma positive samples in the panel could also be related to the age of the samples, as the more sensitive individual primers PCR also failed to detect mycoplasmal DNA in these two samples.

Efforts to investigate community acquired pneumonia are generally poor. As illustrated in 
this study, of the retrospective sputum samples collected over one winter in a large teaching hospital, only 36 of $244(14.8 \%)$ had an acute blood sample sent for investigation and none had a convalescent sample. Many cases of atypical infection would have gone unrecognised without proper investigation. The use of PCR on sputum, which is usually collected when pneumonia is suspected, will help to improve the diagnosis. Prolonged and asymptomatic shedding of mycoplasma and chlamydia has been reported in both healthy individuals and immunodeficient patients. ${ }^{32-34}$ Prolonged shedding of $M$ pneumoniae from the respiratory tract has been demonstrated for up to seven months after acute infection. ${ }^{35}$ During an epidemic, $13.5 \%$ of healthy volunteers was found to carry $M$ pneumoniae in the throat, but this fell to $4.6 \%$ during the interepidemic period. ${ }^{35} \mathrm{C}$ pneumoniae has also been found to persist in atherosclerotic lesions and in peripheral blood mononuclear cells. ${ }^{36}{ }^{37}$ However, one should be aware that using a sensitive PCR technique it is possible to detect persistent non-viable bacterial genome for a prolonged period. The diagnostic relevance should therefore be examined carefully in each case. For patients who had clinical respiratory infection, detection of these organisms in respiratory samples in the absence of other respiratory pathogens should be considered as potentially important. Owing to the lack of other supportive investigations and the retrospective nature of the study, the analysis of the case notes of the 11 patients in this series did not provide a clear cut answer as to whether the episode of illness was caused by the identified organism. Several of the patients (Nos 1, 3, 4, 5, and 8) were initially treated with antibiotics not appropriate for mycoplasma or chlamydia and appeared to have a prolonged illness (table 2). In contrast, two younger patients (Nos 9 and 10) with no underlying illness who had detectable $C$ pneumoniae DNA in their sputum appeared to get better when treated with an inappropriate antibiotic. If $C$ pneumoniae were the causative agents in these two patients, this may reflect the self limiting nature of this infection in otherwise healthy young individuals. The detection of $C$ psittaci DNA in an elderly patient with heart failure is puzzling. The lack of investigations and detailed clinical history in this case make assessment difficult. Amoxycillin is not recommended as a treatment for $C$ psittaci but it may have some effect on chlamydia. Also, the strategy for diagnosis of $C$ psittaci in this multiplex PCR assay was that of exclusion and it is possible that there may be other forms of unrecognised but related respiratory chlamydial infection. Overall, we believe that in at least eight patients in this series, the finding of mycoplasma or chlamydia could be clinically relevant.

The prevalence of atypical organisms in this clinical series was much lower than in other similar studies, ${ }^{1-3}$ and no dual infections were detected. However, our clinical series was comparatively small and was only collected over one winter, which was not in an epidemic year for $M$ pneumoniae. Also, although some samples in this series were sent to the hospital by general practitioners, most were from within the hospital which also restricted the spectrum of disease studied. The hospital based nature of the collection also explained the predominance of older patients with underlying predisposing factors. Mycoplasma and chlamydia were thought to be the cause of pneumonia mainly in young adults. ${ }^{1}$ However, the importance of these organisms to the elderly population has recently been emphasised. ${ }^{38}$ In this study, the exclusive use of sputum as a sample has restricted the spectrum of disease that we investigated as most patients with atypical pneumonia had non-productive cough. A study of throat swabs or nasopharyngeal swabs in such circumstances may provide a greater yield.

To conclude, we have successfully developed a multiplex PCR that can simultaneously detect and differentiate three causative agents of atypical pneumonia. Further optimisation may improve its sensitivity further. To study the usefulness of this assay in a clinical context, it is necessary to carry out prospective studies covering both epidemic and non-epidemic years, using different types of respiratory samples in both hospital and primary care settings.

This study was funded by the NHS North West biomedical research funding scheme (RDO/22/3). The late Dr J Treharne of the Institute of Ophthalmology, London, kindly supplied us with the $C$ pneumoniae IOL207 strain. We thank A Kearns of the Newcastle Public Health Laboratory for supplying the M pneumoniae strain.

1 Thom D, Grayston J, Wang SP, et al. C. pneumoniae strain TWAR, M. pneumoniae and viral infections in acute respiratory disease in a university student health population. $A m$ f Epidemiol 1990;132:248-56.

2 Bartlett JG, Mundy LM. Community acquired pneumonia. N Engl F Med 1995;333:1618-24.

3 Steinhoff D, Lode H, Ruckdeschel G, et al. C. pneumoniae as a cause of community acquired pneumonia in hospitalised patients in Berlin. Clin Infect Dis 1996;22:958-64.

4 CDSC. Mycoplasma pneumoniae surveillance. Commun Dis Rep CDR wkly 1991;1:49.

5 CDSC. Current respiratory infections. Commun Dis Rep CDR wkly 1995;5:21.

6 Forsey T, Darougar S, Treharne JD. Prevalence in human beings of antibodies to Chlamydia IOL-207, an atypical strain of chlamydia. I Infect 1986;12:145-52.

7 Peeling RW, Brunham RC. Chlamydiae as pathogens: new Peeling RW, Brunham RC. Chlamydiae as pathogens:
species and new issues. Emerg Infect Dis 1996;2:307-19.

8 Wreghitt TG, Taylor CED. Incidence of respiratory tract Wreghitt TG, Taylor CED. Incidence of respiratory tract
chlamydial infections and importation of psittacine birds. chlamydial infection $1988 ; \mathrm{i}: 582$.

9 Andrews BE, Major R, Palmer SR. Ornithosis in poultry workers. Lancet 1988;i:632-4.

0 Krause DC, Taylor-Robinson D. Mycoplasma which infect humans. In: Maniloff J, McElhaney RN, Finch LR, Baseman JB, eds. Mycoplasmas. Molecular biology and pathogenesis. Washington DC: ASM Press, 1992:417-44.

11 Kuo CC, Chen HH, Wang SP, et al. Identification of a new group of Chlamydia psittaci strains called TWAR. $\mathcal{F}$ Clin Microbiol 1986;24:1034-7.

12 Baseman JB, Dallo SF, Tully JG, et al. Isolation and characterisation of $\mathrm{M}$. genitalium strains from the human respiratory tract. F Clin Microbiol 1988;26:2266-9.

13 Clyde WA, Kenny GE, Schachter J. Laboratory diagnosis of chlamydial and mycoplasmal infections. Cumitech 19. Washington DC: ASM press, 1984.

14 Advisory Committee on Dangerous Pathogens. Categorisation of biological agents according to hazard and categories of containment, 4th ed. London: HMSO, 1995.

15 Sillis M. Mycoplasma pneumoniae. Lancet 1991;337:1101. 6 Jacobs E. Serological diagnosis of Mycoplasma pneumoniae infections: a critical review of current procedures. Clin Infect Dis 1993;17(suppl 1):S89-82.

17 Bourke SJ. Chlamydial respiratory infections. Common but difficult to diagnose. $B M \mathcal{F}$ 1993;306:1219-20.

18 McFarlane JT, Colville A, Guion A, et al. Prospective study of aetiology of adult lower-respiratory-tract infections in the community. Lancet 1993;341:511-14.

19 McFarlane JT, Prewett J, Rose D, et al. Prospective case control study of role of infection in patients who reconsult control study of role of infection in patients who reconsult
after initial antibiotic treatment for lower respiratory tract infection in primary care. BMF 1997;315:1206-10. 
20 Kai M, Kamiya S, Yabe H, et al. Rapid detection of Mycoplasma pneumoniae in clinical samples by the polymerase chicrobiol 1993;38:166-70.

21 de Barbeyrac B, Bernet-Poggi C, Febrer F, et al. Detection of Mycoplasma pneumoniae and Mycoplasma genitalium in clinical samples by polymerase chain reaction. Clin Infect Dis 1993;17(suppl 1):S83-9.

22 Cadieux N, Lebel P, Brousseau R. Use of a triplex polymerase chain reaction for the detection and differentiation of $\mathrm{Myco}-$ plasma pneumoniae and Mycoplasma genitalium in the presence of human DNA. F Gen Microbiol 1993;139:2431-7.

23 Holland SM, Gaydos CA, Quinn TC. Detection and differentiation of Chlamydia trachomatis, Chlamydia psittaci, and Chlamydia pneumoniae by DNA amplification. F Infect Dis 1990;162:984-7.

24 Campbell LA, Melgosa MP, Hamilton DJ, et al. Detection of Chlamydia pneumoniae by polymerase chain reaction. $\mathcal{F}$ Clin Microbiol 1992;30:434-9.

25 Tong CYW, Sillis M. Detection of Chlamydia pneumoniae and Chlamydia psittaci in sputum samples by PCR. 7 Clin and Chlamydia psittaci in

26 Gaydos CA, Eiden JJ, Oldach D, et al. Diagnosis of Chlamydia pneumoniae infection in patients with communityacquired pneumonia by polymerase chain reaction enzyme . Infect Dis 1994:19:157-60.

27 Sillis $M$. The limitations of IgM assays in the serological diagnosis of Mycoplasma pneumoniae infections. $7 \mathrm{Med}$ Microbiol 1990;33:253-8.

28 Narita M, Matsuzono Y, Togashi T, et al. DNA diagnosis of central nervous system infection by Mycoplasma pneumoniae. Pediatrics 1992;90:250-3

29 Orle KA, Gates CA, Martin DH, et al. Simultaneous PCR detection of Haemophilus ducreyi, Treponema pallidum and herpes simplex virus type 1 and 2 from genital ulcers. $\mathcal{F}$ Clin Microbiol 1996;34:49-54.
30 Bassiri M, Mardh PA, Domeika M, The European Chlamydia Epidemiology Group. Multiplex AMPLICOR PCR screening for Chlamydia trachomatis and Neisseria gonorrhoeae in women attending non-sexually tran
disease clinic. $\mathcal{F}$ Clin Microbiol 1997;35:2556-60.

31 Hajia M, Storey C. Simultaneous detection of Chlamydia pneumoniae and Mycoplasma pneumoniae by PCR. Proceedings of the third meeting of the European Society for Chlamydia research, Vienna, September 11-14, 1996: 312.

32 Gaydos CA, Fowler CL, Gill VJ, et al. Detection of Chlamydia pneumoniae by polymerase chain reaction-enzyme immunoassay in an immunocompromised population. Clin Infect Dis 1993;17:718-23.

33 Hyman CL, Roblin PM, Gaydos CA, et al. Prevalence of asymptomatic nasopharyngeal carriage of Chlamydia pneumoniae in subjectively healthy adults: assessment by polymerase chain reaction-enzyme immunoassay and culture. Clin Infect Dis 1995;20:1174-8.

34 Gnarpe J, Lundback A, Sundelof B, et al. Prevalence of Mycoplasma pneumoniae in subjectively healthy individuals. Scand F Infect Dis 1992;24:161-4.

35 Foy HM, Grayston JT, Kenny GE, et al. Epidemiology of Mycoplasma pneumoniae infection in families. $7 A M A$ 1966;197:859-66.

36 Kuo C-C, Shor A, Campbell LA, et al. Demonstration of Chlamydia pneumoniae in atherosclerotic lesions of coronary arteries. F Infect Dis 1993;167:841-9.

37 Boman J, Soderberg S, Forsberg J, et al. High prevalence of Chlamydia pneumoniae DNA in peripheral blood mononuclear cells in patients with cardiovascular disease and in middle-aged blood donors. F Infect Dis 1998;178:274-7.

38 Wort SJ, Rogers TR. Community acquired pneumonia in elderly people. BMF 1998;316:1690. 